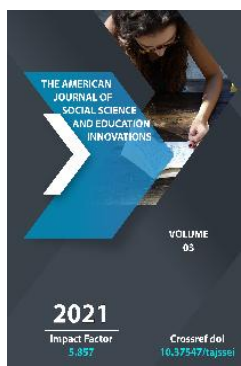

\title{
The Ratio Of Traditions And Innovations In Sports Martial Arts
}

\author{
Nuriddin Sangirov
}

Associate Professor, Department Of Physical Education And Sport, Tashkent State Pedagogical University Named After Nizami, Uzbekistan

Journal Website:

http://theamericanjour

nals.com/index.php/taj

ssei

Copyright: Original content from this work may be used under the terms of the creative commons attributes 4.0 licence.

\section{ABSTRACT}

The article presents the results of studying some aspects of the relationship between traditions and innovations in wrestling and martial arts based on the methods of theoretical collection and analysis of information. The data obtained indicate that the knowledge of traditions and innovations in wrestling and various martial arts allows us to better understand the trends in the development of sports, the features of its functioning, as well as to make assumptions about the prospects for its further development.

\section{KEYWORDS}

Traditions, induction, deduction, wrestling, innovations, sports, martial arts, judo, karate, Aikido, interaction.

\section{INTRODUCTION}

Traditions and innovations, as we know, are categories of the cultural approach. They are an objectively existing reality, which so far rarely comes to the attention of specialists in the field of sports, in particular, in wrestling and martial arts $[3,4]$. At the same time, the 
study of sports through the prism of the correlation of traditions and innovations can allow us to identify certain trends, mechanisms for the development of sports and plan the prospects for their further approval in the sports world. The relevance of this work is determined by the fact that such studies concerning the correlation of traditions and innovations in various martial arts in Russia and in the former USSR countries have not actually been conducted yet.

\section{METHODS AND ORGANIZATION OF THE STUDY}

The study used the analysis and generalization of data from special literature, cultural and acmeological approach, induction, deduction, comparison. The study was conducted on the basis of Belgorod State University, T. G. Shevchenko Pridnestrovian State University, and West Kazakhstan University of Innovation and Technology in 2018-2019.

\section{DISCUSSION OF THE RESEARCH RESULTS}

As the research has shown, the correlation of traditions and innovations is a phenomenon that is objectively present in all the diversity of modern life. When we say the word "new", then at the same time we naturally oppose it to something old, old, and therefore "traditional". The expressions "innovations", "new technologies", "innovations", "traditions" and similar concepts are widely used in various types of human activity. Since physical culture is a "type of culture of society", it is fully closely related to the concepts of "tradition" and "innovation" both in theory and in practice of physical culture and sports activities. This article deals with only three aspects of the relationship between traditions and innovations in the types of wrestling.

The first aspect is the origin of the type of wrestling, martial arts. In practice, there are several main ways of the appearance of wrestling in each individual country. The first method is the origin of the struggle on the basis of their own national ideas, origins, historical prerequisites, features of the development of everyday life, cultural customs, etc. Such types of wrestling are called "folk" or "national". They exist in many countries as their own national traditions (for example, in Kazakhstan - wrestling "kazakhsha kures", in Moldova - "trynta", in Kyrgyzstan - "kurash", in Tatarstan - "koresh", in Yakutia - "hapsagai", in Georgia "chidaoba", in Latvia - "hey dar", in Uzbekistan - "kurash", and so on). These types of wrestling or martial arts, born as folk phenomena, later became and are becoming popular sports wrestling. For example, in the Kazakh wrestling "kazakhsha-kures" the Championships of Asia, Europe and the world are already held. Thus, we can observe how a specific cultural and historical phenomenonnational wrestling (the tradition of the people) gradually becomes a sport (innovation).

Another way is to borrow the struggle that was born in one country (tradition), by another country (innovation). In Russia and in other countries of the former USSR, such types of wrestling (martial arts) should include, first of all, the cultural traditions of Japan (judo, karate, aikido), China (wu-shu, wing-chun), Korea (taekwondo). In this case, the adaptation of foreign traditions naturally occurs, which as a result can lead to the 
"rebirth" of the old tradition in the form of a struggle with new national characteristics. For example, there is an expression "Russian karate"in narrow circles of specialists.

There are also situations when a new type of wrestling appears as a result of the compilation of various types of martial arts. The classic case is the creation of SAMBO wrestling (an innovation based on borrowing many national traditions of other peoples). This trend has actually appeared for a long time and currently it continues to develop actively (a vivid example is mixed martial arts, built on impact and throwing techniques).

The next aspect concerns the problem related to the formation and functioning of federations of sports wrestling and various martial arts. The problem is quite acute and painful. It happens that there is a new type of wrestling, martial arts, which is becoming very popular. In the process of its development, several competing federations are created simultaneously or at different times. They are fighting among themselves for undisputed primacy and recognition with varying success. In order to reduce sports competition, or completely remove it for a while, in one type of wrestling (single combat), many different versions and styles are often created. In other cases, on the contrary, they try to unite forces into a single federation or association.

The third aspect relates to the rules of the competition, where traditions and innovations also interact. As the history of the development of sports wrestling (martial arts) shows, innovations here appear in order to eliminate controversial points in the conduct of the fight and determine the winners, increase the dynamism of fights, increase their entertainment.

\section{CONCLUSION}

The conducted research shows that the types of wrestling and various martial arts have actually always represented and represent the most interesting cultural phenomenon of the dialectical interaction of traditions and innovations in the course of historical development. At the same time, in each type of wrestling (single combat), it is possible to distinguish both specific relations of traditions and innovations, and general typical patterns. It is revealed that the most common innovations are not of the absolute type, but of the relative type. The appearance of innovations necessarily has certain reasons, practical reasons.

Research in this direction makes it possible to better understand the existing trends in the development of wrestling and martial arts, their dynamics and allows you to successfully search for ways, approaches to effectively manage this process in the present and build certain forecasts, plans for the future.

\section{REFERENCES}

1. Выдрин, В.М. Современные проблемы теории физической культуры как вида культуры: Учебное пособие / В.М. Выдрин. СПбГАФК им. П.Ф. Лесгафта. 2001. - 76 с.

2. Николаев, Ю.М. Теория физической культуры: современные подходы: Учебнометодическое пособие / Ю.М. Николаев. СПб.: Олимп- СПб., 2010. $120 \mathrm{C}$. 
3. Собянин, Ф.И. Особенности возникновения новых видов спорта / Ф.И. Собянин, Т.А. Миронова, Е.А. Арсеенко, О.И. Самолюк // Вестник Тамбовского университета. Серия: Гуманитарные науки. 2017. Т.22. № 4 (168). - C. 74-80.

4. Тенденции развития спортивной борьбы в начале третьего тысячелетия: Сборник научных трудов / Под ред. А.Г. Левицкого, Б.И. Тараканова. - СПб.: СПбГАФК им. П.Ф. Лесгафта, 2003. - 174 С.

5. Atxamdjanovna, F. K. (2020, December). Effectiveness of physical culture education effects of adolescents on scientific thinking in growth location of effective information. In Конференции.

6. Farfieva, K. A. (2021). Theoretical Fundamentals of Scientific And Innovative Thinking In Adolescents. The American Journal of Social Science and Education Innovations, 3(04), 431437. 